\title{
Community, institutions and technology in effective utilisation of common property resources: A case of community aquaculture
}

\author{
P. R. SAHOO ${ }^{1}$, P. N. ANANTH ${ }^{1}$, B. K. PATI ${ }^{2}$, B. K. BANJA ${ }^{1}$ AND J. K. SUNDARAY ${ }^{3}$ \\ ${ }^{1}$ Krishi Vigyan Kendra-Khordha, ICAR-Central Institute of Freshwater Aquaculture, Bhubaneswar - 751002 \\ Odisha, India \\ ${ }^{2}$ College of Fisheries, Orissa University of Agriculture and Technology, Berhampur - 760 007, Odisha, India \\ ${ }^{3}$ ICAR-Central Institute of Freshwater Aquaculture, Bhubaneswar - 751 002, Odisha, India \\ e-mail:sahoo_prs@yahoo.com
}

\begin{abstract}
The present study is based on the demonstration of composite fish culture in 15 villages spread in five blocks of Khordha District covering an area of 28.2 ha during the period 2010-11 to 2014-15 by Krishi Vigyan Kendra- Khordha, ICAR-Central Institute of Freshwater Aquaculture, Bhubaneswar. The community ponds were selected in the adopted villages and the demonstration was expansively participatory involving community in all phases of the intervention. Capacity building and skill demonstration on the scientific management practices were provided to the groups involved in the process. In some of the community ponds, critical inputs were provided partially to motivate the group. The results of the study indicated that average fish yield of the adopted community ponds was $2441 \mathrm{~kg} \mathrm{ha}^{-1}$ against the pre-adoption production level of $1571.8 \mathrm{~kg} \mathrm{ha}^{-1}$. The average increase in fish production and net income were 58.22 and $88.72 \%$ respectively with increased average benefit cost ratio from 1.878 to 2.37. After withdrawal of KVK from the adopted villages, the communities continued the practices and are in contact for advisory services. The study concludes that community participation, institutional commitment and viable technology are mandatory to effectively utilise common property resources for supporting rural livelihoods.
\end{abstract}

Keywords: Community pond, Composite fish culture, Demonstration, KVK, Rural aquaculture

\section{Introduction}

Community, institutions and technology are important for deriving livelihoods from common property resources. One of the key freshwater resources that can be used for expanding aquaculture is the community ponds. The community ponds in India are common property resources and have always conflicting interests and are founded on the principles of common interest groups working together by sharing equal responsibilities and risks regardless of sex and age. These community ponds have been serving as effective tools for implementing scientific aquaculture programs in India.

Government of India through development schemes have promoted aquaculture in community ponds along with the state extension machinery. Odisha State in India is endowed with diversified freshwater resources having immense potential for fish culture. Majority of these freshwater resources in rural Odisha falls under community ponds (67\%) vested with local community/ institutions and local self government for multiple use and multiple users (Sinha, 1999). The biggest concern is about the low yield due to low input from these ponds and due to its multiple uses (Katiha et al., 2005). It is estimated in Odisha that the average productivity of fish from community ponds are $317 \mathrm{~kg} \mathrm{ha}^{-1}$ (Barik, 2016). Adoption of scientific management practices in community ponds are constrained by government policy on leasing period and value, community participation and lack of institutional support. It is in this context that robust technology and institutions are keys for community based aquaculture.

Krishi Vigyan Kendra (KVK)-Khordha under the administrative control of ICAR-Central Institute of Freshwater Aquaculture, Bhubaneswar, Odisha has been working with community water bodies to introduce composite fish culture through a participatory mode, over the years.

Community approaches in fish production has been reported by many authors (Radheyshyam, 1999, 2009, 2013; Sinha, 1999; De and Saha, 2005, 2007; Ananth et al., 2014; Sahoo et al., 2016; De et al., 2016) but only a few cases of demonstrations of community-based aquaculture are on record (Lakshmanan et al., 1978; Sinha and Ranadhir, 1980; Sharma and Thakur, 1988; 
Radheyshyam and Tripathy, 1992; Radheyshyam, 1998, 2000, 2002).

This paper presents the attempts of KVK in promoting adoption of community aquaculture through scientific management practices in different parts of the operational area of Khordha District in the state of Odisha, India.

\section{Materials and methods}

The study was conducted in Khordha District of Odisha in which the KVK is mandated to work. The district possesses 2041 Gram Panchayat ponds and 883 Revenue Tanks covering an area of 882.33 ha and 349.02 ha respectively (DFO, 2014). To demonstrate scientific management practices of composite fish culture, the KVK purposively selected 15 villages from five blocks viz., Balianta, Balipatna, Tangi, Bolagarh and Banapur covering an area of 28.2 ha during the period 2010-11 to 2014-15. The selection of ponds was based on the community participation, assessment of the pond situation and leadership among the community members. Before adoption and during the demonstration, periodic data on water quality parameters were observed using standard procedures (APHA, 1998). The data on input use, yield and economic impact of yields were also observed in a participatory mode. Simple percentage analysis was employed to bring inferences to the study.

\section{Management of the demonstration}

Frontline demonstrations (FLD) of KVK are meant to demonstrate frontier technologies to farmers before scaling up at the district level by the state department or the concerned agencies.

Community ponds under the study were selected based on the community participation and the willingness of members to adopt scientific management practices. The average size of selected ponds ranged from 0.8 to 2.1 ha. Before the demonstration, farmers were trained on different aspects of composite fish culture in community ponds. Skill items imparted in the trainings focussed on pre-stocking managements like pond preparation, pond manuring, liming and post-stocking managements like feeding, water quality testing, disease and their control measures and partial harvesting in community ponds. Critical inputs like quality fish seed, lime, groundnut oil cakes as feed ingredients were partially provided by KVK to the groups to ensure active participation and encouragement. Efforts were initiated to create linkage with the Assistant Fisheries Officers of the state government and local banks for availing government schemes and institutional credit.

\section{Demonstration of composite fish culture}

As the demonstration was conducted in participatory mode, the participation of each individual involved in the process was ensured. Aquatic weeds were removed manually by the group. Repeated netting was done for the removal of weed and predatory fishes. Seeds of Indian major carps (IMCs) viz., catla (Catla catla) rohu (Labeo rohita), mrigal (Cirrhinus mrigala) and chinese carp like grass carp (Ctenopharyngodon idella) were stocked with a combined stocking density of $8000 \mathrm{ha}^{-1}$. The seeds were sourced from KVK, ICAR-CIFA and State Fish Farm. Feeding was done with rice bran and groundnut oil cake in 1:1 ratio. Pond fertilisation was done with raw cow dung, urea and single super phosphate in fortnight basis (Ayyappan et al., 2011). Sampling of fish was done monthly to assess the biomass and health status. Basket feeding was encouraged to reduce the wastage of feed and to ensure feed consumption. Extension literatures were provided for enriching the knowledge of farmers and wide spread of the technology. Record keeping was done by the group itself to keep the track on credit flow and net return.

\section{Results and discussion}

\section{Adoption of scientific management practices}

KVK demonstrated composite fish culture in an area covering 28.2 ha in five years from 2010-11 to 2014-15 spread in five blocks of the district (Table 2). Across the demonstration in five blocks, 140 active members from 15 villages were involved. Comparison of water quality parameters recorded in the ponds before adoption and during demonstration are presented in Table 1. All the community ponds adopted the recommend practices with full participation and based on the water quality parameters, can be concluded as full adoption. Following proper liming and fertilisation schedule, the water quality in demonstration ponds was brought within the suitable range for carp culture as reported by other authors (Jena et al., 1998, Sahu et al., 2007). As most of the community ponds were not dewatered/dried since more than 5-10 years, the water quality and soil status were not up to the desired level for intensive fish culture. Application of lime enhanced the water quality and removal of aquatic weed enhanced fish growth and suitability of water for domestic purposes.

Table 1 . Important water quality parameters recorded

\begin{tabular}{lll}
\hline $\begin{array}{l}\text { Water quality } \\
\text { parameters }\end{array}$ & $\begin{array}{l}\text { Before } \\
\text { adoption }\end{array}$ & $\begin{array}{l}\text { During } \\
\text { demonstration }\end{array}$ \\
\hline $\mathrm{pH}$ & $6.90-7.65$ & $7.48-8.34$ \\
Dissolved oxygen $\left(\mathrm{mg} \mathrm{l}^{-1}\right)$ & $2.3-4.67$ & $4.21-5.56$ \\
Total alkalinity $\left(\mathrm{mg} \mathrm{CaCO}^{-1}\right)$ & $45-74$ & $72-108$ \\
Total hardness $\left(\mathrm{mg} \mathrm{CaCO3}^{-1}\right)$ & $32-60$ & $58-92$ \\
Total ammonia-nitrogen $\left(\mathrm{mg} \mathrm{l}^{-1}\right)$ & $0.45-0.98$ & $0.37-0.78$ \\
Nitrite-nitrogen $\left(\mathrm{mg} \mathrm{l}^{-1}\right)$ & $0.035-0.097$ & $0.05-0.12$ \\
Nitrate-nitrogen $\left(\mathrm{mg} \mathrm{l}^{-1}\right)$ & $0.46-0.89$ & $0.41-0.78$ \\
Phosphate-phosphorus $\left(\mathrm{mg} \mathrm{l}^{-1}\right)$ & $0.57-0.78$ & $0.55-0.86$ \\
\hline
\end{tabular}




\section{Input usage and share}

Inputs are critical for adoption of scientific management practices and success of the demonstration is ensured if input supply is proper and adopted as per recommendations. The average share of various inputs in variable cost in FP (Farmer Practice) and RP (Recommended Practice) are represented in Fig. 1 and 2 respectively. It was observed that a large proportion of total input cost was spent on the purchase of supplementary feed by all groups. The reason for spending more on feed cost is due to the high cost of feed ingredients and knowing the importance of feeding to fish. The lease period and cost differed from one community pond to other and the share towards lease value of ponds remains same because ponds with three or more

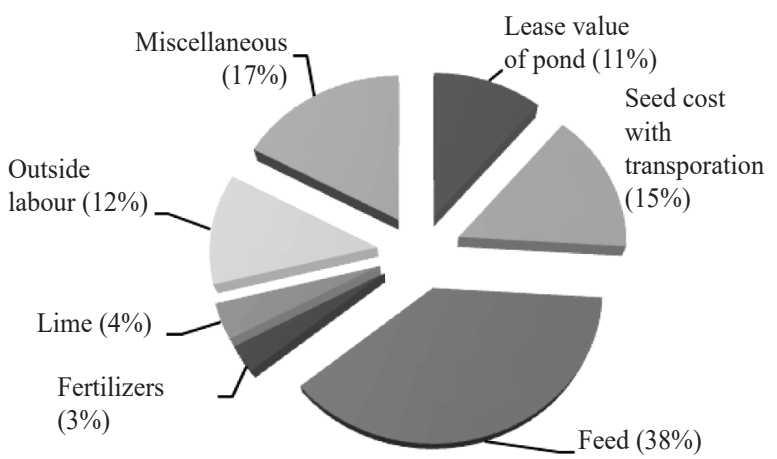

Fig. 1. Average share of different inputs in Farmers Practice (FP) years of lease period were selected for the demonstration. Share of inputs viz., seed cost with transportation, hiring of outside labour and miscellaneous cost decreased in RP and share of inputs like feed cost, lime cost and fertiliser cost increased in RP over FP. This is due to the adoption of scientific management practices and application of recommended dose in appropriate time, which helps in reducing the total cost of culture. The reduction in the share of fish seed cost is due to the restriction of seed stocking density to $8000 \mathrm{ha}^{-1}$ in RP, while FP farmers stock more than the recommended number without maintaining size uniformity. Uniformity of seed size and stocking of recommended number in RP enhances the production level through proper feed management (Radheyshyam et al., 2009). The reduction in the cost of hiring outside labour in RP is due to saving of time and manpower through scientific management practices and follow-up of different activities like weed clearance, basket/bag feeding, fertilisation and liming schedule. Partial harvesting method ensured regular flow of income in RP. The increase in share of feed in RP is mainly due to inclusion of protein component like ground nut oil cake in the ration. In RP, increase in share of fertiliser is due to periodic fertilisation on fortnight basis and increase in lime share is due to application of recommended dose of lime according to the results of water quality testing.

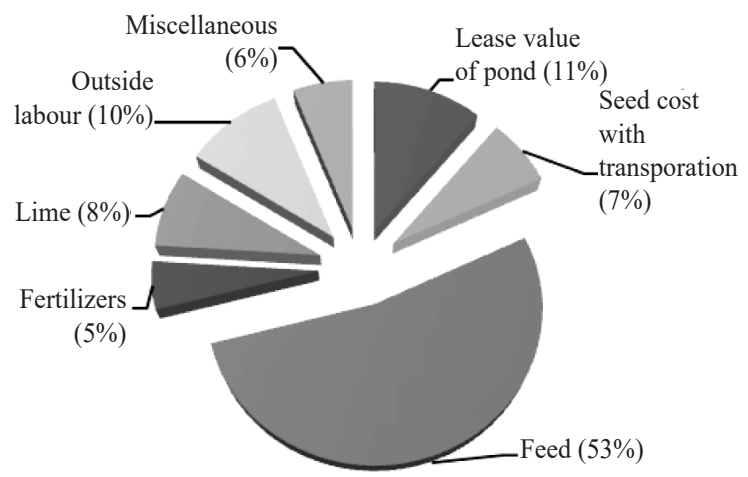

Fig. 2. Average share of different inputs in Recommended Practice (RP)

According to the group, before adoption, they never knew about the protocol of liming and fertiliser application.

\section{Yield analysis}

Farmers Practice (FP) represents the pre-adoption production and Recommended Practice (RP) represents the production in the demonstration year. The average fish yield in FP and RP was $15.718 \mathrm{q} \mathrm{ha}^{-1}$ and $24.41 \mathrm{q} \mathrm{ha}^{-1}$ respectively (Table 2). The increase in average fish yield in different years of adoption is represented in Fig. 3. The increase in fish production was calculated taking FP as

Table 2. Average fish production (Year wise)

\begin{tabular}{|c|c|c|c|c|c|}
\hline \multirow{2}{*}{ Year } & \multirow{2}{*}{ Total average area (ha) } & \multicolumn{2}{|c|}{ Average yield $\left(\mathrm{q} \mathrm{ha}^{-1}\right)$} & \multirow{2}{*}{$\begin{array}{l}\text { Community involved } \\
\text { (Active members) }\end{array}$} & \multirow{2}{*}{ No. of villages } \\
\hline & & FP & RP & & \\
\hline $2010-11$ & 4.8 & 10.9 & 21.12 & 25 & 2 \\
\hline 2011-12 & 6.2 & 15.46 & 22.14 & 30 & 2 \\
\hline $2012-13$ & 5.8 & 12.82 & 19.92 & 25 & 3 \\
\hline 2013-14 & 5.4 & 19.3 & 28.7 & 30 & 3 \\
\hline $2014-15$ & 6.0 & 20.11 & 30.17 & 30 & 3 \\
\hline Average & 5.64 & 15.718 & 24.41 & - & - \\
\hline Total & 28.2 & - & - & 140 & 15 \\
\hline
\end{tabular}

FP: Farmers Practice; RP: Recommended Practice 


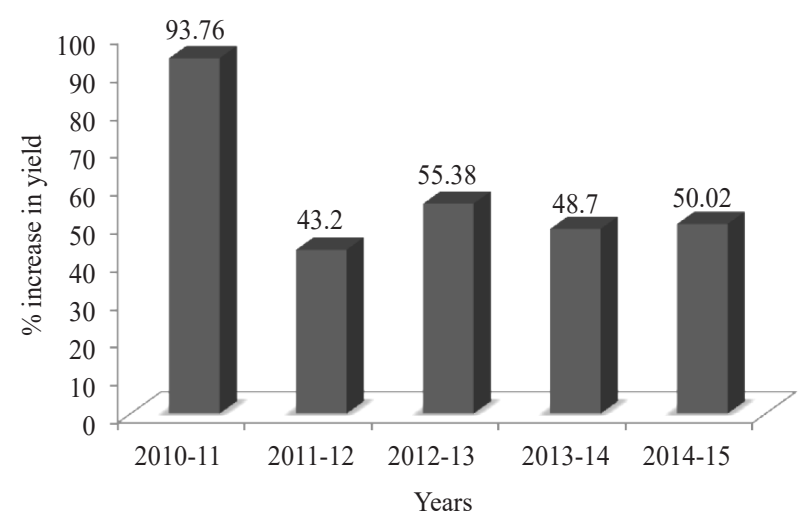

Fig. 3. Percentage increase in fish yield (Year-wise). (Increase in fish production was calculated taking pre-adoption year as base year)

the base year (pre-adoption year). The average increase in fish yield in five years was $58.21 \%$ with highest and lowest increase of 93.76 and $43.2 \%$ respectively. A constant increase in the yield indicates the production potential of community ponds for fish culture. The increase in fish production after adoption mainly depends on the productivity (nutrient status) of the community ponds, motivation and involvement of the group (group dynamics) and adoption rate of scientific management practices (De and Saha, 2005; Radheyshyam, 2001).

The average cost of fish culture, average gross return, average net return and benefit-cost ratio are reflected in Table 3. The average cost of fish culture per hectare increased from ₹78889.6 to ₹97515.8. Average net return increased from ₹71980.2 to ₹135844.4 and benefit-cost ratio from 1.87 to 2.37 indicating a good return and profitable venture for the community as indicated by Dash et al. (2008). Percentage increase in average net income is shown in Fig. 4. The increase in the net return and benefit-cost ratio is mainly due to the judicious use of inputs and adoption of scientific management practices i.e. recommended stocking density, supplementary feeding ration, liming and fertilisation at periodic intervals on the basis of water quality testing results.

Short term lease period of community ponds

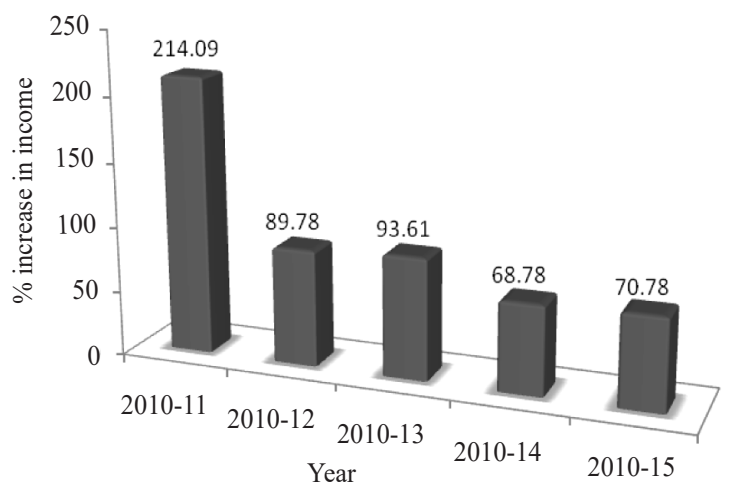

Fig. 4. Percentage increase in average net income. (Increase in net income was calculated taking pre-adoption year as base year)

discourages the groups to invest more in the fish culture towards repair of dikes, clearance of aquatic weeds and maintenance of water and soil quality. Old community ponds have more weeds and are a menace (Kumar, 1992) which drastically reduces fish production. Radheyshyam et al. (2013) in his study suggested that factors like short lease period, stocking of small size seed, use of less quantity of supplementary feed and less exposure to technology adoption led to reduced fish production in community ponds in Odisha. However, the Government of Odisha has extended the lease period to five years under the new Odisha Fisheries Policy 2015. Persistence of social issues and challenges in community leads to failure in community based aquaculture (De and Saha, 2005). Ananth et al. (2014) and Sahoo et al. (2016) reported the constraints faced in practicing aquaculture as high cost of feed, lack of financial support, poor retention of water in ponds, disease outbreak and issues related to lease period and value. Their study emphasised that institutions are vital for the welfare and updating of technical know-how to achieve higher fish production from community ponds.

The present study concludes that community-based fish culture in village ponds is technically feasible, economically viable and socially acceptable. After five years of demonstration by $\mathrm{KVK}$, farmers have been

Table 3. Economic impact of the demonstration in FP and RP

\begin{tabular}{|c|c|c|c|c|c|c|c|c|}
\hline \multirow{2}{*}{ Year } & \multicolumn{2}{|c|}{ Average cost $\left(₹ \mathrm{ha}^{-1}\right)$} & \multicolumn{2}{|c|}{ Average gross return $\left(₹ \mathrm{ha}^{-1}\right)$} & \multicolumn{2}{|c|}{ Average net return $\left(₹ \mathrm{ha}^{-1}\right)$} & \multicolumn{2}{|c|}{ Benefit-cost ratio } \\
\hline & FP & $\mathrm{RP}$ & FP & $\mathrm{RP}$ & $\mathrm{FP}$ & $\mathrm{RP}$ & FP & $\mathrm{RP}$ \\
\hline $2010-11$ & 57820 & 76547 & 87309 & 169171 & 29489 & 92624 & 1.51 & 2.21 \\
\hline $2011-12$ & 87946 & 98500 & 146870 & 210330 & 58924 & 111830 & 1.67 & 2.13 \\
\hline $2012-13$ & 64439 & 78198 & 121790 & 189240 & 57351 & 111042 & 1.89 & 2.42 \\
\hline 2013-14 & 87467 & 112955 & 187180 & 281260 & 99713 & 168305 & 2.14 & 2.49 \\
\hline $2014-15$ & 96776 & 121379 & 211200 & 316800 & 114424 & 195421 & 2.18 & 2.61 \\
\hline Average & 78889.6 & 97515.8 & 150869.8 & 233360.2 & 71980.2 & 135844.4 & 1.87 & 2.37 \\
\hline
\end{tabular}

FP: Farmers Practice; RP: Recommended Practice 
convinced that fish production from community ponds can be enhanced and this has motivated other villagers to approach KVK for support in demonstration and for other advisory services. The study has provided substantial evidence that institutions coupled with technology can carry forward community ponds to be more productive. Government needs to work on formalising a best practice to be adopted across the state for promoting fish culture in community ponds. One time support by the government for community ponds to clean the old ponds, provide technical expertise and adoption of best practices is a pre-requisite as they are common property resources. This study provides evidence that even after the withdrawal of KVK from these villages, communities have been continuing the recommended practices, which gives an encouraging note.

It is also recommended that extensive work needs to be carried out to understand the social and institutional viability of approaches under different socio-cultural and institutional environments as well as to design appropriate institutional arrangements for the diverse type of social settings. Successful group approaches can increase the adoption rate and spread of the technology. Fish culture management in community ponds can potentially lead to greater income in the groups and can provide much needed impetus to the growth and diversification of rural economy.

\section{References}

Ananth, P. N., Sahoo, P. R., Dash, A. K., Pati, B. K., Jayasankar, P. and Singh, S. R. K. 2014. A study on community based aquaculture promoted by KVK-Khordha, Odisha, India. Current World Environ., 9(3): 947-951.

APHA 1998. Standard methods for the examination of water and wastewater, $20^{\text {th }}$ edn. American Public Health Association, Washington, DC:, USA, p. 10-203. .

Ayyappan, S., Moza, U., Gopalakrishnan, A., Meenakumari, B., Jena, J. K. and Pandey, A. K. 2011. Handbook of fisheries and aquaculture. Directorate of Knowledge Management in Agriculture, Indian Council of Agricultural Research, New Delhi, 1116 pp.

Barik, N. K. 2016. Transformation of multiple use water bodies for freshwater aquaculture. Determinants of technology adoption and collective action: a study in Odisha. Agricul. Economics Res. Rev., 28: 167-175.

Dash, H. K., Sahoo, P. K. and Biswal, J. 2008. Aquaculture potential of derelict water bodies - A case study. Agrl. Econ. Res. Rev. 21(2): 265-272.

De, H. K., Radheyshyam, Saha, G. S., Safui, L., Chandra, S., Adhikary, S., Barik, N. K. and. Eknath, A. E. 2016. Impact of aquaculture field school on community fish farming. Indian J. Fish., 63(2): 154-158.
De, H. K. and Saha, G. S. 2007. Community-based Aquaculture An evaluation. J. Rural Dev., 26(1): 137-146.

De, H. K. and Saha, G. S. 2005. Community based aquacultureissues and challenges. Aquaculture Asia, 10(4): 8-9.

DFO 2014. Disaster management plan of Fisheries department 2014-15. Directorate of Fisheries, Odisha, p. 69.

Jena, J. K., Aravindakshan, P. K., Chandra, S., Muduli, H. K. and Ayyappan, S. 1998. Comparative evaluation of growth and survival of Indian major carps and exotic carps in raising fingerlings. J. Aquac. Trop., 13(2): 143-150.

Katiha, P. K. , Jena, J. K. , Pillai, N. G. K., Chakraborty, Chinmoy and Dey, M. M.2005. Inland aquaculture in india: past trend, present status and future prospects. Aquac. Econ. Manag, 9(1): 237- 264

Kumar, D. 1992. Fish culture in un-drainable ponds: A manual for extension. FAO Fishery Technical paper No. 325. Food and Agriculture Organisation, Rome, 239 pp.

Lakshmanan, M. A. V., Rao, N. G. S., Rout, M. and Kanaujia, D. R. 1978. Record fish production through intensive fish culture in a farmer's pond. J. Inland. Fish. Soc. India, 10: 19-27.

Radheyshyam 1998. Community aquaculture utilising swampy water bodies in rural area through adaptive management practices - A case study in Orissa, In: Thomas, P. C. (Ed.), Current and emerging trends in aquaculture. Daya Publishing House, New Delhi, p. 340-347.

Radheyshyam 1999. Siula, India - A success story in community based freshwater aquaculture. ICAR-Central Institute of Freshwater Aquaculture, Bhubaneswar, 18 pp.

Radheyshyam and Tripathy, N. K. 1992. Aquaculture as nucleus for integrated rural development - An experience. Fishing Chimes, 12(9): 37-48.

Radheyshyam 2001. Community based aquaculture in India strengths, weaknesses, opportunities and threats. NAGA, ICLARM Quart, 24(1\&2): 9-12.

Radheyshyam, Ayyappan, S., Safui, L. and Sahu, B. B. 2002. Community-based aquaculture towards food security for rural poor - an observation. In: Ayyappan, S., Jena, J. K. and Mohan, M. Joseph (Eds.), The Fifth Indian Fisheries Forum Proceedings, Asian Fisheries Society Indian Branch, Mangalore and Association of Aquaculturists, Bhubaneswar, India, p. 395-399.

Radheyshyam, De, H. K. and Saha, G. S. 2009. Role of community in production and supply of larger quality fingerlings. Aquac. Asia, 14(1): 16-17.

Radheyshyam, Saha, G. S., Safui, L., Eknath, A. E., Adhikari, S., De, H. K., Barik N. K. and Chandra, S. 2013. Status and economy of community fish farming in rural Odisha. Indian J. Fish., 60(4): 59-67.

Radheyshyam, Satpathy, B. B., Sarkar, S. K. and Safui, L. 2000. Kantapada success story - Marching forward with the aquaculture, ICAR-Central Institute of Freshwater Aquaculture, Bhubaneswar, $50 \mathrm{pp}$. 
Sahoo, P. R., Ananth, P. N., Dash A. K., Pati, B. K., Barik, N. K. and Jayasankar, P. 2016. Institution based intervention on promoting composite fish culture in rural Odisha: A case of KVK-Khordha. Int. J. Fis. Aquatic Stud., 4(4): 190-195.

Sahu, P. K., Jena J. K., Das, P. C., Mondal, S. and Das, R. 2007. Production performance of Labeo calbasu (Hamilton) in polyculture with three Indian major carps Catla catla (Hamilton), Labeo rohita (Hamilton) and Cirrhinus mrigala (Hamilton) with provision of fertilisers, feed and periphytic substrate as varied inputs. Aquaculture, 262: 333-339.
Sharma, B. K. and Thakur, N. K. 1988. Performance of carp culture technology at the rural front. The First Indian Fisheries Forum Proceedings, Asian Fisheries Society Indian Branch, Mangalore, p. 49-50.

Sinha, V. R. P. 1999. Rural aquaculture in India. Rap Publication, Food and Agriculture Organisation of the United Nations, Bangkok, Thailand, 84 pp.

Sinha, V. R. P. and Ranadhir, M. 1980, Potential and constraints of small-scale freshwater fish culture enterprises in India. Proc. IPFC, 19(3): 526-38. 